\title{
RENAL CELL CARCINOMA METASTASIS OF THE SPINE: BLEEDING CONTROL METHODS
}

\author{
METÁSTASE DE CARCINOMA DE CÉLULAS RENAIS DA COLUNA VERTEBRAL: MÉTODOS \\ DE CONTROLE DE SANGRAMENTO
}

\section{METÁSTASIS ESPINAL DE CARCINOMA DE CÉLULAS RENALES: MÉTODOS DE CONTROL DE SANGRADO}

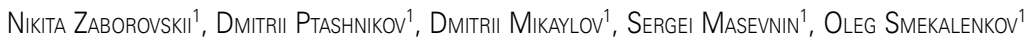

1. Spine Surgery and Oncology Service. R.R.Vreden Russian Research Institute of Traumatology and Orthopedics, Saint-Petersburg, Russia.

\begin{abstract}
Objective: This report compares various methods of bleeding control, and their influence on outcome and survival after decompression procedures for spinal metastasis of renal cell carcinoma (MRCC). Methods: A retrospective study. All patients underwent palliative decompression procedures. We compared 3 groups of patients stratified by methods of bleeding control. The first group (EMB) included 22 patients who underwent preoperative embolization of a tumor. The second group (HEM) consisted of 20 patients, treated surgically using intraoperative local hemostatic agents. In the third group (COMBI) 15 patients were treated with a combination of methods. Results: The average intraoperative blood loss for the EMB group was slightly less than the average for the HEM and COMBI groups, but without significant differences. The postoperative drainage loss in the HEM and COMBI groups was significantly less than in EMB group. The complication rate (infections, hematomas, neurological deficit) was practically equal in all groups. No statistically significant differences in local tumor recurrence and overall survival were found between groups. Conclusions: The overall results did not show that usage of different bleeding control methods can affect early or long-term outcomes. Level of Evidence III; retrospective study.
\end{abstract}

Keywords: Renal cell carcinoma; Embolization; Hemostasis; Treatment outcome.

\section{RESUMO}

Objetivo: Este artigo compara vários métodos de controle de sangramento, sua influência no resultado e sobrevida após procedimentos de descompressão para metástases espinhais de carcinoma de células renais (MRCC). Métodos: Estudo retrospectivo. Todos os pacientes foram submetidos a procedimentos de descompressão paliativa. Comparamos três grupos de pacientes estratificados por métodos de controle de sangramento. O primeiro grupo (EMB) incluiu 22 pacientes submetidos à embolização pré-operatória de um tumor. O segundo grupo (HEM) consistiu em 20 pacientes tratados cirurgicamente usando agentes hemostáticos locais intra operatórios. No terceiro grupo (COMBI), 15 pacientes foram tratados com uma combinação de métodos. Resultados: A perda de sangue intra-operatória média para o grupo EMB foi ligeiramente inferior à média nos grupos HEM e COMBI ,sem diferenças significativas. A perda de drenagem pós-operatória nos grupos HEM e COMBI foi significativamente menor do que no grupo EMB. A taxa de complicações (infecções, hematomas, déficit neurológico) foi quase igual em todos os grupos. Não houve diferença estatisticamente significativa na recorrência local do tumor e a sobrevida global foi encontrada entre os grupos. Conclusões: Os resultados globais não mostraram que o uso de diferentes métodos de controle de sangramento pode afetar os resultados precoce e de longo prazo. Nível de Evidência III; Estudo retrospectivo.

Descritores: Carcinoma de células renais; Embolização; Hemostasia; Resultado do tratamento.

\section{RESUMEN}

Objetivo: Este estudio compara varios métodos de control de sangrado, su influencia en el resultado y la supervivencia después de los procedimientos de descompresión de metástasis espinal de carcinoma de células renales (CCR). Métodos: Estudio retrospectivo en el que todos los pacientes fueron sometidos a procedimientos de descompresión paliativa. Comparamos 3 grupos de pacientes estratificados por métodos de control de sangrado. El primer grupo (EMB) incluyó a 22 pacientes sometidos a embolización preoperatoria de un tumor. El segundo grupo (HEM) consistió en 20 pacientes, tratados quirúrgicamente con agentes hemostáticos locales intraoperatorios. En el tercer grupo (COMBI) 15 pacientes fueron tratados con una combinación de métodos. Resultados: La pérdida de sangre intraoperatoria promedio en el grupo EMB fue ligeramente menor que el promedio en los grupos HEM y COMBI, pero sin diferencias significativas. La pérdida por drenaje posoperatorio en los grupos HEM y COMBI fue significativamente menor que en el grupo EMB. La tasa de complicaciones (infecciones, hematomas, déficit neurológico) fue prácticamente igual en todos los grupos. No se encontraron diferencias estadísticamente significativas en la recurrencia local del tumor y la supervivencia general entre los grupos. Conclusiones: Los resultados generales no mostraron que el uso de diferentes métodos de control de sangrado pueda afectar los resultados a corto o largo plazo. Nivel de Evidencia III; Estudio retrospectivo.

Descriptores: Carcinoma de células renales; Embolización; Hemostasis; Resultado del tratamiento.

Study conducted at the R.R.Vreden Russian Research Institute of Traumatology and Orthopedics, Saint-Petersburg, Russia.

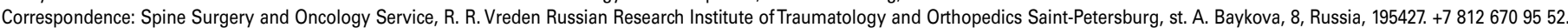
n.zaborovskii@yandex.ru 


\section{INTRODUCTION}

Metastatic bone tumors in the spine are painful and debilitating, challenging to treat and often require surgery. Surgical intervention aims at decompression, either by direct removal of tumor tissue or indirectly, by palliative posterior laminectomy, and is intended to preserve or regain neurological functions, restore or improve walking, and relieve pain. ${ }^{1}$

Spinal metastases originating from renal cell carcinoma (MRCC) are difficult to manage due to profuse intraoperative bleeding, which is difficult to control. The range of techniques, available for sparing blood in spine procedures, is very wide and the variety of concepts is large. ${ }^{2,3}$ The benefit of preoperative embolization in spinal metastases surgery has been reported in previous studies. ${ }^{4-6}$ On the other hand, the use of local hemostatic agents is safe and beneficial for the control of bleeding during spine surgery. ${ }^{7-9}$

This report describes the comparison of various MRCC bleeding control methods, and their influence on outcome and survival after decompression procedures.

\section{METHODS}

The study was approved by the research ethics committee. All patients gave the informed consent prior to being included in the study.

A retrospective analysis was conducted of 57 cases involving patients treated during the period 2005 to 2014. The inclusion criteria were: (1) single-level tumor lesions, (2) patients with extension of tumor around the spinal cord (Wenstein-Boriani-Biagini layer D, Bilsky Epidural Spinal Cord Compression scale >1B), (3) hypervascularity of tumor, (4) posterior decompression surgery. Exclusion criteria were: previous operations, preoperative anemia $(<12 \mathrm{~g} / \mathrm{dL})$, long postembolization period ( $>3$ days), and coagulopathy. All patients received a radiological work-up with plain films, CT, MRI and additional diagnostic angiography. The tumor lesions were mainly located in the thoracic spine ( $n=39 ; 68.4 \%)$, with a smaller percentage of tumors in lumbar spine $(n=18 ; 31.6 \%)$. All 57 patients were stratified by methods of bleeding control into 3 groups. (Table 1) Preoperative embolization was performed in 22 cases (EMB group). In the period 2005-2009 we did not have modern LHA in our practice. Twenty patients were treated surgically using intraoperative LHA for economic reasons (patients have to pay for embolization), or contraindications for embolization, or patient's refusal to undergo the embolization procedure (HEM group). A combination of methods (embolization and hemostatic agents) was used in 15 cases (COMBI group)

\section{Surgical strategy}

The indications for palliative surgical treatment of spinal metastases were neurological deficit, spinal neoplastic instability and the presence of visceral metastases. These indications were true for patients with poor life expectancy, for whom a likelihood of improving the quality of life was expected. All patients were operated by the same team of spine surgeons using standardized techniques. Palliative management included tumor excision in a piecemeal fashion (intralesional excision) by wide laminectomy and spinal instrumentation using the posterior approach. Opening of tumor lesion as late as possible is the most important point in the surgical strategy for hypervascular tumor decompression. Decompression was started via facetectomy at the levels above and below the affected vertebra. Laminectomy (same level and level above) was performed by rongeurs. After visualization of the nerve roots, pedicle was removed from less affected side than from the other side. Decompression of ventral part of neural elements (spinal cord, dural sac) was achieved by bent curettes. Circular decompression should be completed as fast as possible. After tumor tissue removal, tamponade of the cavity provided hemostasis.

\section{Methods of bleeding control}

General measures used to minimize blood loss included the assessment and correction of coagulopathy, hypotensive anesthesia, antifibrinolytic drugs, and the use of bipolar electrocautery, Cell Saver, oxidized cellulose and bone wax.

Diagnostic angiography and embolization under local anesthesia were performed using the femoral approach. Selective catheterization of tumor feeding arteries was performed, and angiographic images were obtained. Tumor vascularity was analyzed by the severity of tumor blush and venous drainage, and evaluated by the interventional radiologist in 4 grades (not hypervascular, mild, moderate, severe). Patients with moderate and severe hypervascularity of tumor were included in the study. We did not perform embolization if any anterior spinal arteries were detected. Gelatin sponge particles were used as embolic material. Embolization was evaluated as "complete" when tumor blush was decreased by more

Table 1. Patients' demographic data

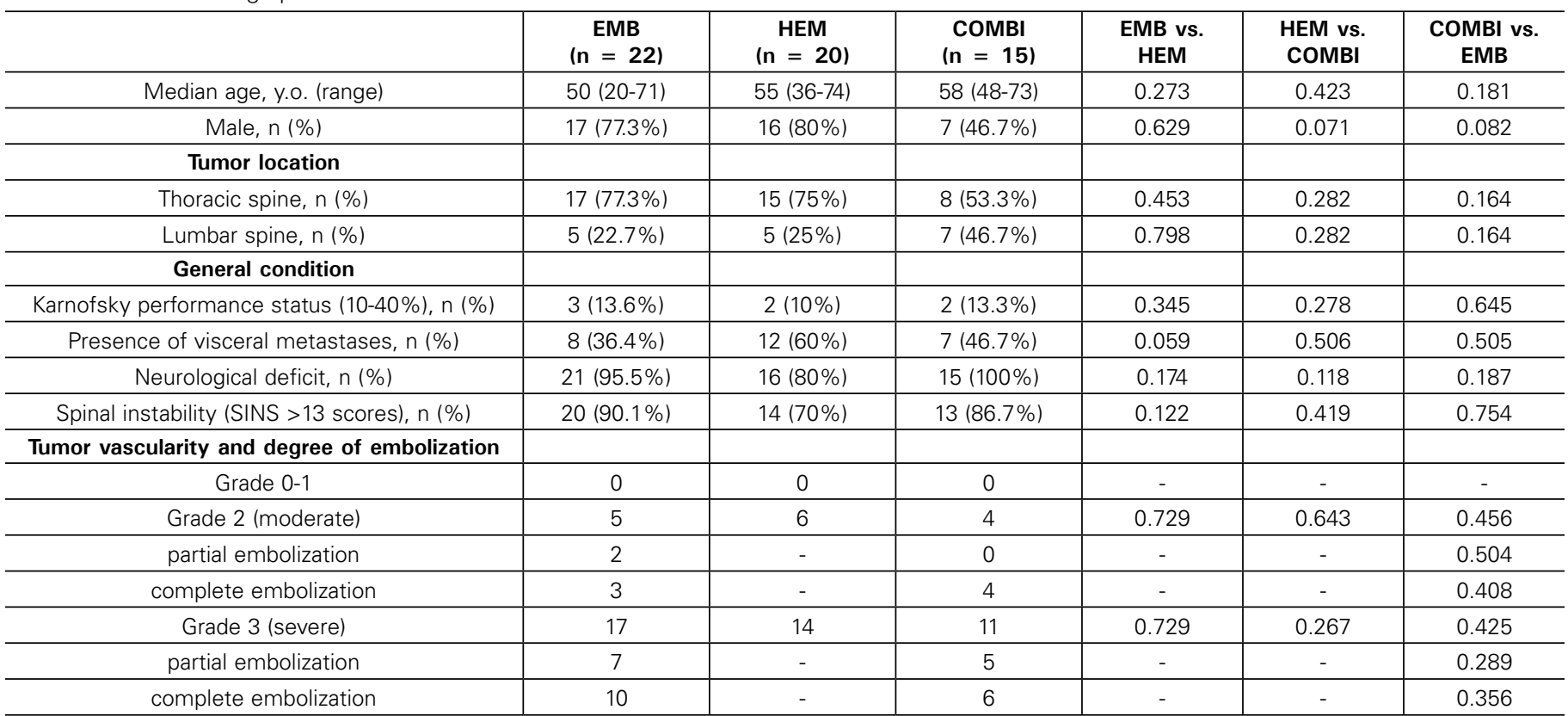

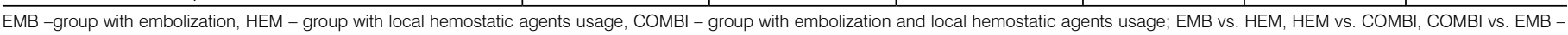
indicates $p$ value between groups. 
than $75 \%$, otherwise it was evaluated as "partial". Most patients who underwent embolization were operated on the next day $(n=26)$, and a smaller number in 2 days $(n=6)$.

Local hemostatic agents were based on a gelatin-thrombin matrix. If profuse bleeding started, a hemostatic was applied to this area. After application of the hemostatic, surgery was continued on another side of the surgical field. If the profuse bleeding did not stop, the hemostatic was reapplied with tamponade. Once the bleeding was under control, it was possible to continue operating on the initial field.

\section{Clinical data}

The parameters evaluated were blood loss volume, drainage loss, possible complications, hospitalization time, and survival. Estimated intraoperative blood loss was obtained from anesthesiologists' records of the amount of blood collected and calculated in the suction container. 100/250 ml Redon-Drainage was used to collect drainage blood loss over 1 week, as standard protocol. Drainage loss volume was recorded daily in the patient's chart. All adverse events during hospitalization were recorded. After hospitalization, patients were observed by oncologists. Overall survival was counted from the end of hospitalization to death.

\section{Statistical Analysis}

Statistical analyses were provided by $R$ version 3.3.2 (R Foundation for Statistical Computing). For categorical variables, cross-tabulations were generated and Pearson's Chi-square test with Yates' continuity correction. The Mann-Whitney $U$ test was used to compare continuous variables between groups. The Kaplan-Meier analysis method estimated postoperative survival, and survival curves using the log-rank test. A p-value less than 0.05 was considered statistically significant.

\section{RESULTS}

Differences between 3 pairs of groups (EMB vs. HEM, HEM vs. $\mathrm{COMBI}, \mathrm{COMBI}$ vs. EMB) were not found preoperatively. The mean intraoperative blood loss for embolized patients was 1129 (range 400-1700) $\mathrm{mL}$, which was slightly less than the mean in groups with LHA - 1235 (range 600-2400) mL and combination of methods 1190 (range 700-1650) mL. Nevertheless, no statistically significant differences were found in blood loss volume between groups. The postoperative drainage loss in the HEM group was 474 (range 190970) $\mathrm{mL}$, and in the COMBI group it was 469 (range 200-620) mL, which was significantly less than that of the EMB group, with 939 (range 370-1450) $\mathrm{mL}$. (Table 2)

The complication rate with reoperation required was nearly equal in all groups. There were 9 hematomas and 7 wound infections, with most of the infections developing from the wound hematomas. Neurological status was evaluated based on the Frankel grade. Postoperatively (at the end of hospital stay), a majority of patients demonstrated improvement in neurological status by at least one Frankel grade (EMB 71.4\% (15/21) patients, HEM 68.8\% (11/16) patients, COMBI
$53.3 \%$ (8/15) patients). $13.5 \%$ (7/ 57) of patients had neurological deterioration caused by operation or the embolization procedure. For example, in the EMB group, one patient developed irreversible paraplegia after embolization. Neurological deterioration (Frankel D to A) was evaluated as rapid decompensation of tumor spinal cord compression. However, after surgery the patient did not improve neurological status. Spinal cord ischemia was diagnosed by MRI. Although preoperative embolization is a relatively safe procedure, there is still a risk of spinal cord ischemia. The mean hospitalization time was significantly shorter in groups with LHA (HEM) compared to groups with embolization (EMB, COMBI).

Secondary neurological deficit following local recurrence of spinal tumor was not associated with embolization or LHA usage, or a combination of the two. The median overall survival was 15.7 (range 4-44) months in EMB group, compared to 19 (range 9-29) month in the HEM group and 14.7 (range 2-25) months in the COMBI group. No statistically significant difference in survival was found between groups by the Log-rank test ( $p=0.360)$.

\section{DISCUSSION}

MRCC are difficult to manage. This type of lesion tends to be large, highly destructive, and more resistant to systemic and radiation therapy than other metastases, resulting in pathological fractures and spinal cord compression that severely compromises the performance status and quality of life of patients. Profuse intraoperative bleeding, caused by metastases of MRCC, is one of the challenges of spine surgery. The majority of spine surgeons believe that embolization of tumor vessels reduces blood loss, lowers surgical risk, and enables more precise dissection and more extensive resection of the lesion. ${ }^{10,11}$ Kobayashi et al. showed that not only embolization, but also the invasiveness of the surgery play an important role in operative blood loss in spinal tumor surgery. ${ }^{12}$ Therefore, we evaluated patients who underwent decompression using the posterior approach.

Some studies describe intraoperative blood loss after embolization and decompression. Guzman et al. showed average blood volume in suction, for patients with embolization in a group with renal cell carcinoma, of $2400 \mathrm{~mL} .{ }^{11}$ Kato et al. reported that intraoperative blood loss after preoperative embolization was twice less than in group without embolization. ${ }^{13}$ Schmidt et al. concluded that for patients with tumor reduction, who underwent preoperative embolization, the mean blood loss was $1867 \mathrm{ml} .{ }^{14}$ In a recent study, Clausen et al. concluded that blood loss differences between patients who received embolization and those who did not were significant, but too small to be clinically important. ${ }^{15}$

We found no statistically significant association between methods of bleeding control (embolization or the application of local hemostatic agents). Therefore, we believe indications for embolization of MRCC before posterior decompression surgery could be reconsidered in the future, as modern hemostatics provide adequate control of hemorrhage in palliative management. This will result in

Table 2. Postoperative data

\begin{tabular}{|c|c|c|c|c|c|c|}
\hline & EMB & HEM & COMBI & $\begin{array}{c}\text { EMB vs. } \\
\text { HEM }\end{array}$ & $\begin{array}{c}\text { HEM vs. } \\
\text { COMBI }\end{array}$ & $\begin{array}{c}\text { COMBI vs. } \\
\text { EMB }\end{array}$ \\
\hline Drainage loss $(\mathrm{mL})$ & $939 \pm 354$ & $464 \pm 127$ & $469 \pm 197$ & $0.011 *$ & 0.564 & $0.045^{*}$ \\
\hline Infection, n of reOp & 3 & 2 & 2 & 0.467 & 0.821 & 0.987 \\
\hline Neurological deficit after embolization, $n$ & 1 & 0 & 1 & 0.999 & 0.428 & 0.999 \\
\hline Neurological deficit after operation, $n$ & 2 & 2 & 1 & 0.978 & 0.981 & 0.956 \\
\hline Hospital stay, days & $33.4 \pm 9.8$ & $26.3 \pm 6.3$ & $31.5 \pm 8.4$ & $0.031^{*}$ & $0.042^{*}$ & 0.368 \\
\hline Local recurrence at outcome, $\mathrm{n}$ & 2 & 1 & 2 & 0.672 & 0.564 & 0.625 \\
\hline Neurological deterioration at outcome, $\mathrm{n}$ & 2 & 2 & 2 & 0.563 & 0.452 & 0.489 \\
\hline
\end{tabular}


decreased surgical risks for oncology patients due to rejection from additional invasive procedures.

Accumulation of blood in the wound carries a risk of infectious complications. ${ }^{16,17}$ The role of local hemostatics in drainage loss after spine tumor surgery has not yet been described. Interestingly, it was proved that drainage loss was significantly lower in the HEM group where local hemostatics were used intraoperatively. Better local hemostasis after hemostatics may be a possible explanation. However, definitive study in this area is needed. Despite hemostatic advantages, wound hematomas may develop. There were cases of revision in these series of patients. However, the number of wound hematomas was not affected by the bleeding control method. We believe that hematomas are caused by development of cavities after paravertebral tumor tissue resection.

The most recent clinical studies have not described any cases of neurological complications. ${ }^{18,19}$ Furthermore, some experimental studies showed no complications after ligation up to 3 or 5 pairs of arteries that may supply the spinal cord arteries. ${ }^{20,21}$ There were 2 (3.7\%) cases of neurological deficit after preoperative embolization in our study; one case of irreversible paraplegia and another with temporary loss of function.

The hospitalization times of the embolized group were longer due to a longer preoperative period. This was mainly influenced by the waiting time for angiography. The length of the postoperative period was similar in all groups.

At present, the goal for every patient with metastatic renal cell carcinoma is to maximize overall therapeutic benefits, which means delaying, for as long as possible, a lethal burden of disease while maximizing the patient's quality of life and convenience.22 Tumor cord compression significantly diminishes the quality of life of cancer patients, creating pain, medical problems such as urogenital infection, pneumonia, and thrombosis. Decompression surgery showed restoration of neurological function. Jackson et al. described survival of 14.1 months after different types of decompression in spinal metastatic renal cell tumor. ${ }^{23}$ Prabhu et al. reported that $37 \%$ of patients survived a mean 11.5 months (range 8.7-21.4 months) after surgery. ${ }^{24}$ Quraishi et al. also found median survival of 12.3 month. ${ }^{25}$ Our average overall survival is slightly longer compared to the results of previous studies. The choice of bleeding control methods did not affect survival in our study.

One of the limitations to the current research is that it was a retrospective analysis of patients' records. Another restriction was the small number of patients evaluated. On the other hand, many studies with relatively small cohorts have been evaluating preoperative embolization since the 1970s. This large volume of information should be associated in meta-analyses for the evaluation of different types of MRCC management, which seems to be possible due to standardized techniques in spine surgery.

\section{CONCLUSIONS}

Our research has proven no significant difference between preoperative embolization of tumor and local hemostatic agents usage in the intraoperative or early postoperative periods, or in long-term outcome. Therefore, we do not see any reason to use expensive and relatively risky procedures of embolization in palliative management of severe hypervascularity renal cell carcinoma metastasis of spine.

\section{ACKNOWLEDGMENTS}

We are indebted to Elena Zavialova and Christopher Downey for their valuable insights and careful reviews of this manuscript.

All authors declare no potential conflict of interest related to this article.

CONTRIBUTION OF THE AUTHORS: NZ (0000-0003-4562-8160* and DP (0000-0001-5765-3158) - active participation in the discussion of results; DM $(0000-0002-4747-0806)^{\star}$, SM $(0000-0003-1085-9890)^{\star}$ and OS $(0000-0002-3586-0487)^{\star}$ review and approval of the final version of the work. *ORCID (Open Researcher and Contributor ID).

\section{REFERENCES}

1. Sciubba DM, Petteys RJ, Dekutoski MB, Fisher CG, Fehlings MG, Ondra SL et al. Diagnosis and management of metastatic spine disease. A review. J Neurosurg Spine. 2010;13(1):94-108.

2. Szpalski M, Gunzburg R, Sztern B. An overview of blood-sparing techniques used in spine surgery during the perioperative period. Eur Spine J. 2005;13(Suppl 1):S18-27.

3. Chivukula S, Weiner G, Engh J.The early days of hemostasis in neurosurgery. Neurosurg Focus. 2014;36(4):E5.

4. Wilson MA, Cooke DL, Ghodke B, Mirza SK. Retrospective analysis of preoperative embolization of spinal tumors. AJNR Am J Neuroradiol. 2010;31(4):656-60.

5. Thiex R, Harris MB, Sides C, Bono CM, Frerichs KU. The role of preoperative transarterial embolization in spinal tumors. A large single-center experience. Spine J. 2013;13(2):141-9.

6. Pikis S, Itshayek E, Barzilay Y, Hasharoni A, Kaplan L, Gomori M et al. Preoperative embolization of hypervascular spinal tumors: current practice and center experience. Neurol Res. 2014;36(6):502-9.

7. Renkens KL, Payner TD, Leipzig TJ, Feuer H, Morone MA, Koers JM et al. A multicenter, prospective, randomized trial evaluating a new hemostatic agent for spinal surgery. Spine (Phila Pa 1976). 2001;26(15):1645-50.

8. Schonauer C, Tessitore E, Moraci A, Barbagallo G, Albanese V. The use of local agents: bone wax, gelatin, collagen, oxidized cellulose. Eur Spine J. 2004;13(Suppl 1):S89-96.

9. Sabel M, Stummer W. The use of local agents: Surgicel and Surgifoam. Eur Spine J. 2004;13 (Suppl 1):S97-101.

10. Olerud C, Jónsson H, Löfberg AM, Lörelius LE, Sjöström L. Embolization of spinal metastases reduces peroperative blood loss. 21 patients operated on for renal cell carcinoma. Acta Orthop Scand. 1993;64(1):9-12.

11. Guzman R, Dubach-Schwizer S, Heini P, Lovblad KO, Kalbermatten D, Schroth G et al. Preoperative transarterial embolization of vertebral metastases. Eur Spine J. 2005:14(3):263-8.

12. Kobayashi K, Ozkan E, Tam A, Ensor J, Wallace MJ, Gupta S. Preoperative embolization of spinal tumors: variables affecting intraoperative blood loss after embolization. Acta radiol. 2012;53(8):935-42

13. Kato S, Murakami H, Minami T, Demura S, Yoshioka K, Matsui O et al. Preoperative embolization significantly decreases intraoperative blood loss during palliative surgery for spinal metastasis. Orthopedics. 2012;35(9):e1389-95.
14. Schmidt R, Rupp-Heim G, Dammann F, Ulrich C, Nothwang J. Surgical therapy of vertebral metastases. Are there predictive parameters for intraoperative excessive blood loss despite preoperative embolization? Tumori. 2011;97(1):66-73.

15. Clausen C, Dahl B, Frevert SC, Hansen LV, Nielsen MB, Lönn L. Preoperative embolization in surgical treatment of spinal metastases: single-blind, randomized controlled clinical trial of efficacy in decreasing intraoperative blood loss. J Vasc Interv Radiol. 2015;26(3):402-12

16. Perry JW, Montgomerie JZ, Swank S, Gilmore DS, Maeder K. Wound Infections Following Spinal Fusion with Posterior Segmental Spinal Instrumentation. Clin Infect Dis. 1997;24(4):558-61

17. Xing $\mathrm{D}, \mathrm{Ma} \mathrm{J}-\mathrm{X}, \mathrm{Ma} \mathrm{X}-\mathrm{L}$, Song $\mathrm{DH}$, Wang J, ChenY et al. A methodological, systematic review of evidence-based independent risk factors for surgical site infections after spinal surgery. Eur Spine J. 2013;22(3):605-15.

18. Kato S, Hozumi T, Takaki Y, Yamakawa K, Goto T, Kondo T. Optimal schedule of preoperative embolization for spinal metastasis surgery. Spine (Phila Pa 1976). 2013;38(22):1964-9.

19. Cernoch $P$, Hechelhammer L, von Hessling A, Spross C, Erhardt J, Jost B et al. Preoperative embolisation of spinal metastasis: technique, complication rate and outcome - clinical experience. Int Orthop. 2015;39(7):1399-404.

20. Fujimaki Y, Kawahara N, Tomita K, Murakami H, Ueda Y. How many ligations of bilateral segmental arteries cause ischemic spinal cord dysfunction? An experimental study using a dog model. Spine (Phila Pa 1976). 2006;31(21):E781-9.

21. Ueda Y, Kawahara N, Tomita K, Kobayashi T, Murakami H, Nambu K. Influence on spinal cord blood flow and function by interruption of bilateral segmental arteries at up to three levels: experimental study in dogs. Spine (Phila Pa 1976). 2005;30(20):2239-43.

22. Rini BI, Campbell SC, Escudier B. Renal cell carcinoma. Lancet. 2009;373(9669):1119-32.

23. Jackson RJ, Gokaslan ZL, Loh SC. Metastatic renal cell carcinoma of the spine: surgical treatment and results. J Neurosurg Spine. 2001:94(1 Suppl):18-24

24. Prabhu VC, Bilsky MH, Jambhekar K, Panageas KS, Boland PJ, Lis E et al. Results of preoperative embolization for metastatic spinal neoplasms. J Neurosurg. 2003:98(2 Suppl):156-64

25. Quraishi NA, Purushothamdas S, Manoharan SR, Arealis G, Lenthall R, Grevitt MP. Outcome of embolised vascular metastatic renal cell tumours causing spinal cord compression. Eur Spine J. 2013;22(Suppl 1):27-32. 